\title{
Management algorithms for metastatic prostate cancer
}

Shawn Malone ${ }^{1}$; Bobby Shayegan² ${ }^{2}$ Naveen S. Basappa ${ }^{3}$; Kim Chi ${ }^{4}$; Henry J. Conter ${ }^{5}$; Robert J. Hamilton ${ }^{6}$; Sebastien J. Hotte ${ }^{2}$; Fred Saad ${ }^{7}$; Alan So ${ }^{8}$; Laura Park-Wyllie ${ }^{9}$; Huong Hew ${ }^{9}$; Deanna McLeod ${ }^{10}$; Geoffrey Gotto ${ }^{11}$

${ }^{1}$ The Ottawa Hospital, University of Ottawa, Ottawa, ON, Canada; ${ }^{2} J u r a v i n s k i$ Cancer Centre, McMaster University, Hamilton, ON, Canada; ${ }^{3}$ Cross Cancer Institute, University of Alberta, Edmonton, AB, Canada; ${ }^{4} \mathrm{BC}$ Cancer Agency, Vancouver, BC, Canada; ${ }^{5}$ William Osler Health System, University of Western Ontario, Brampton, ON, Canada; ${ }^{6}$ Princess Margaret Cancer Centre, University of Toronto, Toronto, ON, Canada; ${ }^{7}$ Centre Hospitalier de l'Université de Montréal, University of Montreal, Montreal, QC, Canada; ${ }^{8}$ Vancouver Prostate Centre, University of British Columbia, Vancouver, BC, Canada; ${ }^{9}$ Medical Affairs, Janssen Inc., Toronto, ON, Canada; ${ }^{10}$ Kaleidoscope Strategic Inc., Toronto, ON, Canada; ${ }^{11}$ University of Calgary, Calgary, AB, Canada

ICMJE Disclaimer: This article was prepared according to ICMJE recommendations, with editorial and research assistance from Kaleidoscope Strategic Inc. Janssen Canada supported the development of the algorithm, provided funding for medical writing services and their employees were contributing authors.

Acknowledgements: The authors would like to thank Janssen Canada for funding this initiative, Drs. Jeffrey Spodek, Scott Morgan, Lorne Aaron, Tony Finelli, and Christina Canil for their contributions to algorithm development, and Ilidio Martins and Loretta Collins of Kaleidoscope Strategic Inc. for research and editorial support in preparing the manuscript.

Cite as: Can Urol Assoc J 2019 April 26; Epub ahead of print. http://dx.doi.org/10.5489/cuaj.5840

Published online April 26, 2019

$* * *$
Abstract
Introduction: Prostate cancer poses a significant lifetime risk to Canadian men. Treatment for metastatic prostatic cancer (mPCa) is an area of ongoing research with a lack of up-to-date clinical guidance. The multidisciplinary Canadian Genitourinary Research Consortium (GURC) determined that additional guidance focusing on management of mPCa was warranted.
Methods: The most up-to-date guidelines, consensus statements, and emerging phase 3 trials were identified and used to inform development of algorithms by a multidisciplinary genitourinary oncology panel outlining recommendations for the management of mPCa. 
Results: A single pan-Canadian guideline and five national and international guidelines or consensus statements published since 2015 were identified, along with two new phase 3 trials and one additional randomized comparison. Iterative GURC discussions led to the development of two mPCa algorithms: the first addressing management of newly diagnosed metastatic castration-sensitive prostate cancer (mCSPC) patients and the second addressing treatment of patients with metastatic castration-resistant prostate cancer (mCRPC). For newly diagnosed mCSPC patients with high-volume/high-risk disease, either docetaxel or abiraterone acetate and prednisone (AAP) added to androgen-deprivation therapy (ADT) is recommended. The addition of radiotherapy to ADT is suggested for those with low-volume disease and/or AAP to ADT for low-volume or low-risk disease. For first-line mCRPC, androgen receptor-axis-targeted (ARAT) therapy is recommended for most patients, while sequencing with docetaxel, radium-223, ARAT therapy, and/or cabazitaxel is recommended for later lines of therapy.

Conclusions: Two treatment algorithms were developed for the management of mPC and can be used by multidisciplinary specialist teams to guide treatment.

\section{Introduction}

Prostate cancer (PC) poses a significant lifetime risk to Canadian men. ${ }^{1}$ In 2017, approximately $21 \%$ of all new cancer cases diagnosed among Canadian men were PC (total of 21,300 cases). Every year in Canada, an average of 1,187 (8.6\%) patients are diagnosed with metastatic prostate cancer (mPC). ${ }^{2}$

Treatment for mPC is an active area of research, with new treatment data emerging in recent years. Guidelines and consensus statements address much of this evidence. ${ }^{3-8}$ However, many lack a practical perspective and do not sufficiently address clinical scenarios, such as treatment sequencing, that are not directly informed by phase III data.

The Canadian Genitourinary Research Consortium (GURC) is a national multidisciplinary network of clinical specialists treating advanced PC who collaborate on research, education and establishment of best practices. The GURC Best Practices Working Group (GURC BPW Group) identified the need to develop practical guidance on treatment options and decision-making in mPC and worked to provide physicians with an easy-to-follow practice tool that addressed management of newly diagnosed metastatic castration-sensitive prostate cancer (mCSPC) and metastatic castration-resistant prostate cancer (mCRPC).

\section{Methods}

\section{Algorithm development}

The GURC BPW Group included 5 uro-oncologists, 2 radiation oncologists and 2 medical oncologists, and had pan-Canadian representation. The group held iterative discussions regarding 
the management of patients with mPC, followed by discussion with the GURC Steering Committee. Algorithms outlining treatment of mPC were developed through review of national and international guidelines and consensus statements (see Literature Search below). Final algorithms were approved by both GURC BPW Group and Steering Committee members.

\section{Literature search}

Canadian and major North American and European guidelines and consensus statements addressing management of mPC were identified. PubMed, Google Scholar and the internet were searched from January 2015 to November 4, 2018 using the search string "prostate cancer AND (guideline OR consensus OR recommendations)” and guideline databases (CMA's CPG Infobase: Clinical Practice Guidelines, National Guidelines Clearinghouse and Guidelines International Network) were searched for guidelines or consensus statements using the keyword “prostate”. Recommendations on management options for newly diagnosed mCSPC or mCRPC were extracted from full-text and synthesized for review.

As existing guidelines were current only to June 2018 (NCCN 2018 v4 data cut-off of May 2018), a supplementary search for new data was also performed. PubMed was searched from June 1, 2018 to November 5, 2018 and ASCO and ESMO 2018 annual meeting abstract databases were searched using the search string "prostate cancer AND metastatic AND phase III (OR respective aliases)” for primary reports of original phase III trials investigating mPC treatment and reporting positive or practice changing outcomes. Search results were screened at the abstract level and confirmed at full text.

\section{Results}

\section{Literature search findings and algorithm development}

The literature search identified one pan-Canadian guideline ${ }^{6}$ and five guidelines or consensus statements from major North-American and/or European organizations or groups ${ }^{3-5,7,8}$ published since 2015 (Table 1). Canadian provincial guidelines, ${ }^{9,} 10$ Euroasian single-nation, ${ }^{11-19}$ Asian consensus, ${ }^{20}$ and specialty-focused guidelines ${ }^{21-24}$ were excluded. Outcomes from two new phase III studies ${ }^{25,26}$ and one additional randomized comparison of the phase III STAMPEDE trial ${ }^{27}$ were considered eligible for our review. Although not explicitly stated as such, the HORRAD study was classified as a phase III study based on its randomized design, size, and primary OS end-point, ${ }^{25}$ and both the HORRAD and the STAMPEDE analyses of radiotherapy versus standard of care were included in our review, as subgroup findings in low-volume patients were considered practice changing, even though overall outcomes were negative. ${ }^{25,27}$

The iterative group review and discussion of this data led to the development of two algorithms addressing the management of mPC: the first in newly diagnosed mCSPC (Figure 1A), and the second in mCRPC (Figure 1B). This work builds on a prior publication in which GURC presents two treatment algorithms to guide the management of non-metastatic PC for consideration in the context of individualized therapy, existing guidelines and practice patterns. ${ }^{28}$ 


\section{Recommendations for treatment of newly diagnosed metastatic castration-sensitive prostate cancer (Fig. 1A)}

For patients with mCSPC, androgen deprivation therapy (ADT) should be initiated, with concurrent monitoring to ensure castrate levels of testosterone are achieved. ${ }^{4,8}$ Clinical and disease characteristics should then be considered to determine stage and prognosis. ${ }^{29}$ Discussion of treatment options, including clinical trial enrolment, is best carried out in the context of a multi-disciplinary consult or multi-disciplinary rounds. Consultation with an oncologist or referral to a specialized tertiary centre should be considered when available.

\section{Systemic therapy}

Three phase III studies involving five randomized comparisons have addressed the benefit of adding further systemic treatment to ADT in mCSPC (Table 2). ${ }^{30-36}$ The phase III CHAARTED study enrolled 790 newly diagnosed mCSPC patients. ${ }^{33,34}$ CHAARTED demonstrated a significant improvement in median overall survival (OS) with the addition of docetaxel (75 $\mathrm{mg} / \mathrm{m}^{2}$, q3 weeks x 6) to ADT versus ADT alone (57.6 vs. 47.2 months, HR 0.72, 95\% CI, 0.59$0.89, \mathrm{p}=0.0018$ ). A pre-planned stratified subgroup analysis confirmed the OS benefit of docetaxel in the $65 \%$ of patients with high-volume disease, defined as those with at least one high-volume factor (i.e., visceral metastases, $\geq 4$ bone lesions with $>1$ beyond the vertebral bodies and pelvis; 51.2 vs. 34.4 months, HR 0.63 , 95\% CI 0.50-0.79, $\mathrm{p}<0.001$ ). No OS benefit was observed for docetaxel in the $35 \%$ of patients with low-volume disease (63.5 vs. NR months, HR $1.04,95 \%$ CI $0.70-1.55, \mathrm{p}=0.86$ ), although the analysis may have been underpowered due to small sample size. The addition of docetaxel to ADT was considered both safe and manageable, with neutropenia, febrile neutropenia, and fatigue being the most common adverse events. ${ }^{33,34}$ The phase III LATITUDE study enrolled a total of 1,199 patients with high-risk mCSPC, defined as a positive bone scan or metastatic lesions on CT or MRI and at least two high-risk factors based on visceral metastases, three or more bone lesions and Gleason score 8 to 10 (Table 2) ${ }^{30}$ A significant improvement in median OS was seen for ADT plus abiraterone acetate and prednisone (AAP) compared to ADT plus placebo (not yet reached [NYR] vs. 34.7 months; HR $0.62,95 \%$ CI, $0.51-0.76, \mathrm{p}<0.001) .{ }^{30}$ The addition of AAP to ADT was safe and manageable, with hypertension, hypokalemia, and alanine aminotransferase (ALT) increase being the most common adverse events. ${ }^{30}$

The phase III multi-arm, multi-stage STAMPEDE trial enrolled patients with newly diagnosed mCSPC, node-positive mCSPC, or high-risk locally advanced PC (Table 2), and has reported results from three randomized comparisons addressing the benefits of adding either docetaxel or AAP to ADT. ${ }^{31,32,35}$ The first comparison $(n=2,962)$ demonstrated a significant improvement in median OS for ADT plus docetaxel versus ADT alone (81 vs. 71 months, HR $0.78,95 \%$ CI 0.66-0.93, $\mathrm{p}=0.006),{ }^{32}$ and the second $(\mathrm{n}=1,917)$ a significant improvement OS for ADT plus AAP versus ADT alone (3-year OS, 83\% vs. 76\%, HR 0.63, 95\% CI 0.52-0.76, $\mathrm{p}<0.001) .{ }^{31}$ Pre-planned subgroup analyses based on disease extent confirmed the benefit of adding either agent (docetaxel, HR $0.76,95 \%$ CI $0.62-0.92$, p=0.005 or AAP, HR $0.61,95 \%$ CI 
0.49-0.75) to ADT in metastatic patients. ${ }^{31,32}$ A posthoc analysis of ADT plus AAP versus ADT alone assessing outcomes by risk status (per LATITUDE) and disease volume (per CHAARTED) showed a 3-year OS benefit in high-risk (HR 0.54, 95\% CI 0.41-0.71, p<0.001) and low-risk (HR 0.66, 95\% CI 0.44-0.98, p=0.041), as well as high-volume (HR 0.60, 95\% CI, 0.46-0.78, $\mathrm{p}<0.001$ ) and low-volume (HR 0.64, 95\% CI 0.42-0.97, $\mathrm{p}=0.034$ ) disease. ${ }^{36}$ A third more recent pre-planned but opportunistic study compared docetaxel and AAP directly in newly diagnosed, node-positive mCSPC, or high-risk locally advanced PC patients $(n=556)$. Both agents demonstrated comparable survival overall (HR 1.16, 95\% CI 0.82-0.1.65, p=0.404), as well as in patients with metastatic disease (HR 1.13, 95\% CI 0.77-1.66, p=0.528). ${ }^{35}$ Additionally, safety was comparable between treatment arms and both agents were considered safe and manageable. The most common adverse events (grades 3-5) associated with docetaxel were high rates of febrile neutropenia (17\%), as well as neutropenia (13\%), and endocrine disorders (9\%). Endocrine (13\%), cardiovascular (9\%), musculoskeletal (9\%) and hepatic disorders $(9 \%)$ were the most common adverse events associated with AAP. ${ }^{35}$

\section{Radiotherapy}

A fourth comparison from the STAMPEDE trial assessed the benefit of radiotherapy for newly diagnosed mPC patients. The trial randomized patients $(n=2,061)$ to receive either ADT plus radiotherapy or ADT alone. ${ }^{27}$ Although a failure-free survival benefit in favour of radiotherapy plus ADT versus ADT was observed in patients overall (HR 0.76, 95\% CI 0.68-0.84, p<0.0001), it did not translate into an improvement in the primary end-point of overall survival (median OS, 48 vs. 46 months, HR 0.92, 95\% CI 0.80-1.06, p=0.266). A pre-specified exploratory subgroup analysis by volume of disease per CHAARTED did, however, show improved OS with the addition of radiotherapy to ADT for patients with low metastatic burden (3-year OS, 81\% vs. $73 \%, \mathrm{n}=819$; HR 0.68, 95\% CI 0.52-0.90, p=0.007). No benefit was found for patients with high metastatic burden. Radiotherapy was well-tolerated in the intent to treat population. ${ }^{27}$ These findings are supported by outcomes from the recently published HORRAD randomized trial, which assigned patients with primary bone metastatic PC $(n=432)$ to receive ADT plus radiotherapy or ADT alone. The study showed a non-significant improvement in the primary end-point of OS with the addition of radiotherapy to ADT (median, 45 vs. 43 months, HR 0.90, 95\% CI 0.70-1.14, p=0.4), with a trend similar to that of STAMPEDE showing improved (albeit non-significant) survival among patients with low volume disease $(<5$ metastases; HR 0.68, 95\% CI 0.42-1.10). ${ }^{25}$

Level 1 evidence supports the addition of docetaxel or AAP to ADT for high-volume/risk mCSPC. ${ }^{30,31,33,34,36}$ The addition of docetaxel to ADT has been used in high-volume, fit patients in Canada ${ }^{37-39}$ since release of CHAARTED data in $2015,{ }^{33}$ and the addition of AAP to ADT recently received Health Canada approval (February 2018) for use in high-risk mCSPC. ${ }^{40}$ NCCN and EAU guidelines recommend both docetaxel and AAP as options for high-volume or highrisk groups ${ }^{4,8}$ and, given the high degree of concordance between the definitions of high-volume and high-risk disease as indicated in the CHAARTED and LATITUDE studies (86\%), ${ }^{41}$ GURC 
recommends the addition of either agent to ADT for newly diagnosed mCSPC patients with high-volume/risk disease (Figure 1A).

GURC recommends the addition of either docetaxel or AAP to ADT for newly diagnosed mCSPC patients with high-volume/risk disease

Recommendations for low-volume/risk disease vary across guidelines. ${ }^{3,4,8}$ Based on results of STAMPEDE demonstrating improved OS for the addition of radiotherapy or AAP to ADT in newly diagnosed mCSPC with a low-volume disease ${ }^{27,36}$ and AAP to ADT in low-risk disease, ${ }^{36}$ GURC suggests the addition of radiotherapy to ADT as a treatment option in mCSPC with low-volume disease and/or AAP to ADT in low-volume or low-risk disease (Figure 1A). However, AAP is not yet approved for use in the treatment of low-volume disease in Canada. Upon clinical, radiologic, or PSA progression, as defined by PCWG2 criteria, ${ }^{42}$ treatment for mCRPC should be considered. ${ }^{4,8}$

GURC suggests the addition of radiotherapy or AAP to ADT for newly diagnosed mCSPC patients with low-volume disease and/or AAP to ADT for low-volume or low-risk disease

Recommendations for treatment of newly diagnosed metastatic castration-resistant prostate cancer (Fig. 1B)

CRPC is diagnosed when a patient has rising PSA or clinical or radiological progression, despite castrate levels of testosterone. $^{4-6,8,43}$ At this stage, management is best explored in the context of a genitourinary multi-disciplinary consult. GURC recommends consultation with either a urooncologist and/or medical oncologist for staging and prognostic assessment.

\section{Prognostic stratification}

The APCCC guidelines stratify patients with mCRPC based on features indicative of clinical outcome. Poor prognosis features include small cell histology on a tumour biopsy and/or low or absent androgen receptor expression, exclusive visceral metastases, rapid clinical progression without correlation with PSA kinetics, low PSA levels relative to tumour burden, predominantly lytic bone metastases, short response to ADT ( $\leq 12$ mo.), and bulky tumour masses. ${ }^{3}$ GURC suggests consideration of a similar set of poor prognostic factors including elevated LDH, widespread and/or visceral metastasis, poor performance status (ECOG PS $\geq 2$ ), low hemoglobin, short response (<12 months) to initial ADT, clinical symptoms, elevated alkaline phosphatase, and small cell pathology. ${ }^{44-47}$

First-line treatment of metastatic CRPC 
First-line mCRPC therapy largely depends on patient prognosis. For patients with a poor prognosis, disease progression can be rapid. Therefore, GURC recommends referral to a medical oncologist or multi-disciplinary genitourinary team for monitoring and management. In this setting, treatment should include consideration of docetaxel, enrolment in a clinical trial, or other therapeutic strategies. Current guidelines recommend that treatment selection be made with consideration of performance status, symptoms, comorbidities, location and extent of disease, patient preference, and previous treatment for hormone-sensitive mPC. ${ }^{4,8}$

First-line treatments for non-poor prognosis patients include androgen receptor-axis-targeted (ARAT) treatment, chemotherapy, radio-isotope therapy and immunotherapy (Table 3). Two phase III trials have demonstrated improved median OS for sipuleucel-T versus placebo in asymptomatic or minimally symptomatic mCRPC (25.8 vs. 21.7 mo., HR 0.78, 95\% CI: 0.61$0.98, \mathrm{p}=0.03^{48}$ and 25.9 vs. 21.4 mo., HR $1.70,95 \% \mathrm{CI}, 1.13-2.56, \mathrm{p}=0.01{ }^{49}$ respectively). Sipuleucel-T is not approved or available in Canada and, therefore, will not be discussed further in this article.

Two phase III trials have assessed ARAT therapy in asymptomatic or mildly symptomatic CRPC with no prior docetaxel. PREVAIL showed a significant improvement in median OS for enzalutamide $(n=872)$ versus placebo ( $n=845 ; 32.4$ vs. 30.2 months, HR 0.71, 95\% CI 0.60-0.84, $<<0.001)^{50}$ while the COU-AA-302 demonstrated significantly improved median OS for AAP ( $n=546)$ versus placebo plus prednisone ( $n=542 ; 34.7$ vs. 30.3 mo., HR $0.81,95 \%$ CI $0.70-0.93, p=0.0033$ with pre-specified efficacy boundary, $\alpha=0.0035){ }^{51}$ Two phase III trials showed improved survival for docetaxel among chemotherapy naïve, mCRPC patients. SWOG 99-16 demonstrated improved median OS for docetaxel plus estramustine ( $n=338)$ versus mitoxantrone plus prednisone ( $n=336 ; 17.5$ vs. 15.6 months, HR 0.80, 95\% CI 0.67-0.97, $\mathrm{p}=0.02)^{52}$ and TAX 327 demonstrated improved OS with docetaxel (every 3 weeks) plus prednisone $(n=335)$ versus mitoxantrone plus prednisone $(n=337 ; 18.9$ vs. 16.5 months, HR 0.76, 95\% CI 0.62-0.94, $\mathrm{p}=0.009)^{53}$-a benefit that remained consistent with extended follow-up. ${ }^{54}$ The phase III PRINCE trial demonstrated the non-inferiority of an intermittent schedule of docetaxel based on the primary endpoint of 1-year survival (two-sided 95\% CI -12-18, $\mathrm{p}=0.022){ }^{26}$

The phase III ALSYMPCA trial demonstrated improved median OS for radium-223 $(n=614)$ versus placebo $(n=307)$ in patients with symptomatic bone metastases and free of visceral metastases (14.9 vs. 11.3 months, HR $0.70,95 \%$ CI $0.58-0.83, \mathrm{p}<0.001)^{55}$ as well as in patients with no prior docetaxel ( $\mathrm{n}=349$; 16.1 vs. 11.5 months, HR 0.69, 95\% CI 0.52-0.92, $\mathrm{p}=0.01){ }^{56}$

There is level 1 evidence to support use of ARAT therapy, docetaxel or radium-223 for symptomatic mCRPC and ARAT or docetaxel for asymptomatic mCRPC, ${ }^{26,50-56}$ as well as associated recommendations from the NCCN and EAU guidelines. ${ }^{4,8}$ GURC recommends ARAT therapy alone for first-line mCRPC, keeping in mind that treatment strategy may vary depending on prior therapy received for mCSPC. A recent survey showed that $94 \%$ of 
responding clinicians treating PC in Canada $(n=49)$ selected ARAT therapy as first-line mCRPC therapy. ${ }^{57}$ AAP is now approved for use in mCSPC and as such, the use of AAP in earlier settings may lead to an increase in the use of docetaxel for first-line mCRPC. Upon clinical, radiologic, or PSA progression, as defined by PCWG2 criteria reflective of common clinical practice, consideration of further therapy is recommended.

GURC recommends ARAT therapy first-line for the majority of mCRPC patients, although patients with poor prognosis should be referred to a medical oncologist or multidisciplinary genitourinary team for monitoring and management

Later lines of metastatic CRPC therapy

Selection of second-line treatment is dependent on many factors, including prior treatment exposure as well as clinical and disease characteristics. EAU guidelines recommend consideration of performance status, symptoms, patient preference, comorbidities and extent of disease. ${ }^{4}$ Treatment options for later lines include ARAT therapy, chemotherapy or radium-223 in patients receiving prior docetaxel (Table 4).

Two phase III trials support use of ARAT therapy for mCRPC following docetaxel. COU-AA-301 showed a significant improvement in median OS for AAP $(n=797)$ versus placebo plus prednisone ( $\mathrm{n}=398$; 15.8 vs. 11.2 months, HR $0.74,95 \%$ CI $0.64-0.86, p<0.0001)$, ${ }^{58}$ while AFFIRM showed a similar significant improvement in median OS for enzalutamide $(\mathrm{n}=800)$ versus placebo ( $\mathrm{n}=399 ; 18.4$ vs. 13.6 months, HR 0.63, 95\% CI 0.53-0.75, $\mathrm{p}<0.001) .{ }^{59}$ Chemotherapy and radium-223 are also second-line treatment options. The phase III TROPIC trial showed a significant improvement in median OS for cabazitaxel plus prednisone and $(\mathrm{n}=378)$ versus mitoxantrone plus prednisone ( $\mathrm{n}=377 ; 15.1$ vs. 12.7 months, HR $0.70,95 \%$ CI 0.59-0.83, $\mathrm{p}<0.0001$ ) for patients progressing on first-line docetaxel. ${ }^{60}$ More recently, the phase III ALSYMPCA trial demonstrated a significant improvement in median OS for radium-223 $(n=352)$ versus placebo $(n=174)$ in a subgroup receiving prior docetaxel $(n=526 ; 14.4$ vs. 11.3 months, HR 0.70, 95\% CI 0.56-0.88, $\mathrm{p}=0.002) .^{56}$

There is level 1 evidence for use of ARAT, cabazitaxel and radium-223 as second-line therapy following docetaxel, ${ }^{56,58-60}$ and support for use of docetaxel in this setting is derived primarily from first-line phase III trials, ${ }^{52-54}$ as well as prospective and retrospective cohort studies demonstrating $>25 \%$ PSA response to docetaxel re-challenge following a good response to initial therapy. ${ }^{61-65}$ However, there is little evidence to guide optimal sequencing following first-line treatment of mCRPC with intensive therapy, ${ }^{4-6,8,43}$ and national and international treatment recommendations for later lines of therapy vary. ${ }^{5,6,8,43}$ GURC recommendations take into account available evidence, patterns of practice and access to therapy in providing sequencing options following first-line ARAT therapy (Figure 1B); an individualized approach 
to treatment sequencing is encouraged, along with special consideration of disease burden, symptomatology, prior therapy, drug eligibility and patient preference. At each mCRPC treatment juncture, management strategies should include consideration of palliative and supportive care measures as well as clinical trial eligibility.

For patients with visceral metastases and/or bulky nodes $>3 \mathrm{~cm}$ following first-line ARAT therapy, GURC recommends docetaxel followed by cabazitaxel or ARAT. Referral to a tertiary care centre should be considered for docetaxel ineligible patients. In cases of ARAT or cabazitaxel ineligibility, the alternate agent should be considered. For patients with no visceral metastases or bulky nodes $>3 \mathrm{~cm}$ following first-line ARAT therapy, consideration of patient symptoms is important in guiding therapy. For second and third-line treatment of symptomatic patients, GURC recommends consideration of docetaxel or radium-223 followed by the alternate agent upon progression. For asymptomatic patients, GURC recommends docetaxel while referral to a tertiary care centre is warranted for patients ineligible for docetaxel. For patients progressing on either radium-223 or docetaxel, GURC recommends ARAT or cabazitaxel. In cases of drug ineligibility or lack of access for any line of therapy, the alternate agent should be considered.

GURC recommends an individualized approach to treatment sequencing for later lines of mCRPC therapy, which may include docetaxel, radium-223, ARAT, and cabazitaxel

\section{Discussion}

\section{Strengths and limitations}

The treatment algorithms are presented as practical tools to guide the management of mPC. The therapeutic options suggested for consideration by clinicians are inspired by evidence and reflect the clinical expertise of a multi-disciplinary team of Canadian clinical experts specializing in PC. Although not comprehensive in representation of all available evidence or potential treatments, the algorithms are designed to inspire multi-disciplinary discussion that considers individual disease characteristics, patient history and preferences.

\section{Summary}

The GURC recommendations reflect results of multi-disciplinary clinical discussion, with the goal of providing clear and practical guidance on the management of mPC. The treatment algorithms indicate the addition of ARAT or docetaxel to ADT for newly diagnosed highvolume/high-risk mCSPC, the addition of radiotherapy to ADT for low-volume mCSPC, and/or AAP to ADT for low-volume or low-risk mCSPC. ARAT therapy is recommended for first-line treatment of mCRPC, and sequencing of later lines of therapy should be carried out in an 
individualized manner, accounting for clinical and disease characteristics, and may include docetaxel, radium-233, cabazitaxel or ARAT therapy.

Disclosures: Dr. Malone has served on advisory boards and/or received honoraria from Janssen, Astellas Sanofi, Abbvie, Tersera and Bayer, and has participated in clinical trials sponsored by Janssen and Bayer. Dr. Basappa has served on advisory boards and received honoraria and/or grants from Janssen, Astellas, Bayer, BMS, Pfizer, AstraZeneca, Merck, Ipsen, Eisai and Roche. Dr. Chi has served on advisory boards and received honoraria and/or grant funding from Astellas, Bayer, Janssen, Roche and Sanofi. Dr. Conter has received grants and/or honoraria from Janssen, Astellas, BMS, Novartis and Eli Lilly, and has participated in clinical trials sponsored by Merck, Roche, Takeda, Pfizer and AstraZeneca. Dr. Hamilton has served on advisory boards and/or received honoraria from Janssen, Astellas, Abbvie, Amgen, Tersera and Bayer and has participated in clinical trials sponsored by Janssen and Bayer. Mr. Hew is employed by Janssen Canada. Dr. Hotte has received institutional research funding or consulting honoraria from Astellas, Janssen and Bayer. Ms. McLeod owns Kaleidoscope Strategic, who received funding for preparing this review by Janssen Canada. Ms. Park-Wyllie is employed by Janssen Canada. Dr. Saad has served as a consultant for, and received funding from, Amgen, Astellas, AstraZeneca, Bayer, BMS, Janssen and Sanofi. Dr. Shayegan has received grants or honoraria from Astellas, Janssen, Abbvie and Sanofi, and participated in clinical trials sponsored by Janssen and Astellas. Dr. So has received honoraria and served on advisory boards for Amgen, Astellas, Abbvie, Ferring, Jannsen, Bayer and Sanofi, and participated in clinical trials sponsored by Janssen and Astellas. Dr. Gotto -has received honoraria and served on advisory boards for Amgen, Astellas, Astra Zeneca, Bayer, Janssen, Merck, Sanofi, and Roche, and has participated in clinical trials sponsored by Amgen, Astellas, Astra Zeneca, Bayer, Janssen, and Myovant.

\section{References}

1. Canadian Cancer Society's Advisory Committee on Cancer Statistics. Canadian Caner Statistics 2017. Toronto, ON: Canadian Cancer Society 2017. Available at: http://www.cancer.ca/ /media/cancer.ca/CW/publications/Canadian\%20Cancer\%20Statis tics/Canadian-Cancer-Statistics-2017-EN.pdf; Accessed June 6, 2018.

2. Canadian Cancer Statistics Advisory Committee. Canadian Cancer Statistics 2018. Toronto, ON: Canadian Cancer Society; 2018.;Available at: cancer.ca/Canadian-CancerStatistics-2018-EN; Accessed August 16, 2018.

3. Gillessen S, Attard G, Beer TM, et al. Management of patients with advanced prostate cancer: the report of the Advanced Prostate Cancer Consensus Conference APCCC 2017. Eur Urol. 2018;73:178-211.

4. Mottet N, van den Bergh RCN, Briers E, et al. EAU Guidelines: Prostate Cancer; 2018. Available at: https://uroweborg/guideline/prostate-cancer/ Accessed April 17, 2018.

5. Parker C, Gillessen S, Heidenreich A, et al. Cancer of the prostate: ESMO Clinical Practice Guidelines for diagnosis, treatment and follow-up. Ann Oncol. 2015;26:v69-v77.

6. Saad F, Chi KN, Finelli A, et al. The 2015 CUA-CUOG Guidelines for the management of castration-resistant prostate cancer (CRPC). Can Urol Assoc J. 2015;9:90.

7. Cookson MS, Lowrance WT, Murad MH, et al. Castration-resistant prostate cancer: AUA guideline amendment. J Urol. 2015;193:491-9.

8. National Comprehensive Cancer Network. NCCN Clinical Practice Guidelines in Oncology (NCCN Guidelines ${ }^{\circledR}$ ): Prostate Cancer. Version 2.2018 — March 8, 2018. 
Available at:

https://wwwnccnorg/store/login/loginaspx?ReturnURL=https://wwwnccnorg/professiona ls/physician_gls/pdf/prostatepdf Accessed April 15, 2018.2018.

9. Catton C, Joshua A. Princess Margaret Cancer Centre Clinical Practice Guidelines: Prostate Cancer; 2015. Available at:

http://wwwuhnca/PrincessMargaret/Health_Professionals/Programs_Departments/Genit ourinary_GU/Documents/CPG_GU_Prostatepdf Accessed March 18, 2018.

10. Alberta Health Services. Clinical Practice Guideline: Prostate Cancer GU-004; 2015.Available at: https://www.albertahealthservices.ca/assets/info/hp/cancer/if-hpcancer-guide-gu004-prostate.pdf; Accessed March 18, 2018.

11. Loizaga-Iriarte A, Rodriguez-Antolin A, Miñana B, et al. Castrate resistant prostate cancer. Consensus recommendations of the Spanish Association of Urology. Actas Urol Esp. 2017;41:141.

12. Golabek T, Belsey J, Drewa T, et al. Evidence-based recommendations on androgen deprivation therapy for localized and advanced prostate cancer. Cent European J Urol. 2016;69:131.

13. Climent MÁ, León-Mateos L, del Alba AG, et al. Updated recommendations from the Spanish Oncology Genitourinary Group for the treatment of patients with metastatic castration-resistant prostate cancer. Crit Rev Oncol Hematol. 2015;96:308-18.

14. Ponholzer A, Loidl W, Bektic J, et al. Austrian recommendations on Targeted Hormone Therapy for metastatic, castration-resistant prostate cancer. Wiener klinische Wochenschrift. 2016;128:156-63.

15. National Clinical Effectiveness Committee (Ireland). National Clinical Guideline for the Diagnosis, Staging and Treatment of Prostate Cancer; 2015. Available at:

https://wwwhseie/eng/services/list/5/cancer/profinfo/guidelines/prostate/prostateguidelin epdf Accessed March 18, 2018.

16. Gómez-Caamaño A, González-San Segundo C, Henríquez I, et al. Consensus on management of castration-resistant prostate cancer on behalf of the Urological Tumours Working Group (URONCOR) of the Spanish Society of Radiation Oncology. Clinical and Translational Oncology. 2018:1-13.

17. Brizmohun Appayya M, Adshead J, Ahmed HU, et al. National implementation of multiparametric magnetic resonance imaging for prostate cancer detection-recommendations from a UK consensus meeting. BJU Int. 2018;122:13-25.

18. Bonfill X, Arevalo-Rodriguez I, García LM, et al. Intermittent androgen deprivation therapy: recommendations to improve the management of patients with prostate cancer following the GRADE approach. Cancer Manag Res. 2018;10:2357.

19. Committee CAAGO. Chinese experts consensus on the treatment of metastatic prostate cancer 2018 edition. Zhonghua wai ke za zhi [Chinese journal of surgery]. 2018;56:646.

20. Hinotsu S, Namiki M, Ozono S, et al. NCCN Asia Consensus Statement prostate cancer. Jpn J Clin Oncol. 2018;48:964-5.

21. Poeppel TD, Handkiewicz-Junak D, Andreeff M, et al. EANM guideline for radionuclide therapy with radium-223 of metastatic castration-resistant prostate cancer. Eur J Nucl Med Mol Imaging. 2018;45:824-45. 
22. Du Y, Carrio I, De Vincentis G, et al. Practical recommendations for radium-223 treatment of metastatic castration-resistant prostate cancer. Eur J Nucl Med Mol Imaging. 2017;44:1671-8.

23. McNeel DG, Bander NH, Beer TM, et al. The Society for Immunotherapy of Cancer consensus statement on immunotherapy for the treatment of prostate carcinoma. $J$ Immunother Cancer. 2016;4:92.

24. Lecouvet FE, Oprea-Lager DE, Liu Y, et al. Use of modern imaging methods to facilitate trials of metastasis-directed therapy for oligometastatic disease in prostate cancer: a consensus recommendation from the EORTC Imaging Group. Lancet Oncol. 2018;19:e534-e45.

25. Boevé LM, Hulshof MC, Vis AN, et al. Effect on survival of androgen deprivation therapy alone compared to androgen deprivation therapy combined with concurrent radiation therapy to the prostate in patients with primary bone metastatic prostate cancer in a prospective randomised clinical trial: data from the HORRAD trial. Eur Urol. 2018.

26. Cash H, Steiner U, Heidenreich A, et al. Intermittent vs continuous docetaxel therapy in patients with metastatic castration-resistant prostate cancer-a phase III study (PRINCE). BJU Int. 2018.

27. Parker CC, James ND, Brawley CD, et al. Radiotherapy to the primary tumour for newly diagnosed, metastatic prostate cancer (STAMPEDE): a randomised controlled phase 3 trial. Lancet. 2018:Published online October 21, 2018 http://dx.doi.org/10.1016/S01406736(18)32486-3.

28. Danielson B, Saad F, So A, et al. Management algorithms for PSA progression in prostate cancer: Biochemical recurrence after definitive therapy and progression to nonmetastatic castrate-resistant prostate cancer. Can Urol Assoc J. 2019;In Press.

29. Gravis G, Boher J-M, Fizazi K, et al. Prognostic factors for survival in noncastrate metastatic prostate cancer: validation of the glass model and development of a novel simplified prognostic model. Eur Urol. 2015;68:196-204.

30. Fizazi K, Tran N, Fein L, et al. Abiraterone plus prednisone in metastatic, castrationsensitive prostate cancer. N Engl J Med. 2017;377:352-60.

31. James ND, de Bono JS, Spears MR, et al. Abiraterone for prostate cancer not previously treated with hormone therapy. $N$ Engl J Med. 2017;377:338-51.

32. James ND, Sydes MR, Clarke NW, et al. Addition of docetaxel, zoledronic acid, or both to first-line long-term hormone therapy in prostate cancer (STAMPEDE): survival results from an adaptive, multiarm, multistage, platform randomised controlled trial. Lancet. 2016;387:1163-77.

33. Sweeney CJ, Chen Y-H, Carducci M, et al. Chemohormonal therapy in metastatic hormone-sensitive prostate cancer. $N$ Engl J Med. 2015;373:737-46.

34. Kyriakopoulos CE, Chen YH, Carducci MA, et al. Chemohormonal Therapy in Metastatic Hormone-Sensitive Prostate Cancer: Long-Term Survival Analysis of the Randomized Phase III E3805 CHAARTED Trial. J Clin Oncol. 2018;36:1080-7.

35. Sydes MR, Spears MR, Mason MD, et al. Adding abiraterone or docetaxel to long-term hormone therapy for prostate cancer: directly randomised data from the STAMPEDE multi-arm, multi-stage platform protocol. Ann Oncol. 2018;29:1235-48. 
36. Hoyle A, Ali S, James N, et al. LBA4 Effects of abiraterone acetate plus prednisone/prednisolone in high and low risk metastatic hormone sensitive prostate cancer. Ann Oncol. 2018;29:mdy424. 033.

37. Alberta Health Services. Clinical Practice Guideline: Prostate Cancer GU-010; 2018.Available at: https://www.albertahealthservices.ca/assets/info/hp/cancer/if-hpcancer-guide-gu010-met-prostate.pdf; Accessed October 25, 2018.

38. Tannock IF, Sternberg CN. Many men with castrate-sensitive metastatic prostate cancer should not receive chemotherapy. Ann Oncol. 2016;27:545-6.

39. Parimi S, Chi KN. Chemotherapy for metastatic castration-sensitive prostate cancer. Int $J$ Urol. 2016;23:726-33.

40. Health Canada Approves New Indication for ZYTIGA®* (abiraterone acetate), Broadening its Use for Treatment of Newly Diagnosed Metastatic Prostate Cancer. Available at: http://www.investor.jnj.com/releasedetail.cfm?releaseid=1057632; Accessed on August 23, 2018.

41. Iacovelli R, Ciccarese C, Mosillo C, et al. Comparison Between Prognostic Classifications in De Novo Metastatic Hormone Sensitive Prostate Cancer. Target Oncol. 2018.

42. Scher HI, Halabi S, Tannock I, et al. Design and end points of clinical trials for patients with progressive prostate cancer and castrate levels of testosterone: recommendations of the Prostate Cancer Clinical Trials Working Group. J Clin Oncol. 2008;26:1148.

43. Cookson MS, Roth BJ, Dahm P, et al. Castration-resistant prostate cancer: AUA Guideline. American Urological Association, 2018 Available at: http://wwwauanetorg/guidelines/prostate-cancer-castration-resistant-(2013-amended2018); Accessed July 5, 2018. 2015.

44. Fu SYF, Chi KN. Developing prognostic models for advanced prostate cancer when the goal line keeps changing. Ann Oncol. 2018.

45. Halabi S, Lin CY, Kelly WK, et al. Updated prognostic model for predicting overall survival in first-line chemotherapy for patients with metastatic castration-resistant prostate cancer. J Clin Oncol. 2014;32:671-7.

46. James ND. Prognostic and predictive models in hormone-sensitive prostate cancer. BJU Int. 2018;122:352-3.

47. Terada N, Akamatsu S, Kobayashi T, et al. Prognostic and predictive biomarkers in prostate cancer: latest evidence and clinical implications. Ther Adv Med Oncol. 2017;9:565-73.

48. Kantoff PW, Schuetz TJ, Blumenstein BA, et al. Overall survival analysis of a phase II randomized controlled trial of a Poxviral-based PSA-targeted immunotherapy in metastatic castration-resistant prostate cancer. J Clin Oncol. 2010;28:1099-105.

49. Small EJ, Schellhammer PF, Higano CS, et al. Placebo-controlled phase III trial of immunologic therapy with sipuleucel-T (APC8015) in patients with metastatic, asymptomatic hormone refractory prostate cancer. J Clin Oncol. 2006;24:3089-94.

50. Beer TM, Armstrong AJ, Rathkopf DE, et al. Enzalutamide in metastatic prostate cancer before chemotherapy. $N$ Engl J Med. 2014;371:424-33.

51. Ryan CJ, Smith MR, Fizazi K, et al. Abiraterone acetate plus prednisone versus placebo plus prednisone in chemotherapy-naive men with metastatic castration-resistant prostate 
cancer (COU-AA-302): final overall survival analysis of a randomised, double-blind, placebo-controlled phase 3 study. Lancet Oncol. 2015;16:152-60.

52. Petrylak DP, Tangen CM, Hussain MH, et al. Docetaxel and estramustine compared with mitoxantrone and prednisone for advanced refractory prostate cancer. $N$ Engl J Med. 2004;351:1513-20.

53. Tannock IF, de Wit R, Berry WR, et al. Docetaxel plus prednisone or mitoxantrone plus prednisone for advanced prostate cancer. $N$ Engl J Med. 2004;351:1502-12.

54. Berthold DR, Pond GR, Soban F, et al. Docetaxel plus prednisone or mitoxantrone plus prednisone for advanced prostate cancer: updated survival in the TAX 327 study. J Clin Oncol. 2008;26:242-5.

55. Parker C, Nilsson S, Heinrich D, et al. Alpha emitter radium-223 and survival in metastatic prostate cancer. $N$ Engl J Med. 2013;369:213-23.

56. Hoskin P, Sartor O, O'Sullivan JM, et al. Efficacy and safety of radium-223 dichloride in patients with castration-resistant prostate cancer and symptomatic bone metastases, with or without previous docetaxel use: a prespecified subgroup analysis from the randomised, double-blind, phase 3 ALSYMPCA trial. Lancet Oncol. 2014;15:1397-406.

57. Hotte SJ, Finelli A, Malone S, et al. Real world patterns of treatment sequencing in Canada for metastatic castrate-resistant prostate cancer. J Clinc Oncol 36 (Suppl 6):Abstr 320.

58. Fizazi K, Scher HI, Molina A, et al. Abiraterone acetate for treatment of metastatic castration-resistant prostate cancer: final overall survival analysis of the COU-AA-301 randomised, double-blind, placebo-controlled phase 3 study. Lancet Oncol. 2012;13:98392.

59. Scher HI, Fizazi K, Saad F, et al. Increased survival with enzalutamide in prostate cancer after chemotherapy. $N$ Engl J Med. 2012;367:1187-97.

60. de Bono JS, Oudard S, Ozguroglu M, et al. Prednisone plus cabazitaxel or mitoxantrone for metastatic castration-resistant prostate cancer progressing after docetaxel treatment: a randomised open-label trial. Lancet. 2010;376:1147-54.

61. Caffo O, Pappagallo G, Brugnara S, et al. Multiple rechallenges for castration-resistant prostate cancer patients responding to first-line docetaxel: assessment of clinical outcomes and predictive factors. Urology. 2012;79:644-9.

62. Di Lorenzo G, Buonerba C, Faiella A, et al. Phase II study of docetaxel re-treatment in docetaxel-pretreated castration-resistant prostate cancer. BJU Int. 2011;107:234-9.

63. Eymard JC, Oudard S, Gravis G, et al. Docetaxel reintroduction in patients with metastatic castration-resistant docetaxel-sensitive prostate cancer: a retrospective multicentre study. BJU Int. 2010;106:974-8.

64. Mountzios I, Bournakis E, Efstathiou E, et al. Intermittent docetaxel chemotherapy in patients with castrate-resistant prostate cancer. Urology. 2011;77:682-7.

65. Oudard S, Kramer G, Caffo O, et al. Docetaxel rechallenge after an initial good response in patients with metastatic castration-resistant prostate cancer. BJU Int. 2015;115:744-52.

66. de Bono JS, Logothetis CJ, Molina A, et al. Abiraterone and increased survival in metastatic prostate cancer. $N$ Engl J Med. 2011;364:1995-2005.

67. Bahl A, Oudard S, Tombal B, et al. Impact of cabazitaxel on 2-year survival and palliation of tumour-related pain in men with metastatic castration-resistant prostate cancer treated in the TROPIC trial. Ann Oncol. 2013;24:2402-8. 


\section{Figures and Tables}

Fig. 1. Management of metastatic prostate cancer. (A) Management of newly diagnosed metastatic castration-sensitive prostate cancer. ${ }^{1}$ Ensure castrate levels of testosterone; ${ }^{2}$ Consider determination of alkaline phosphatase levels as prognostic factor (Gravis et al. Eur Urol 2015;68:196-204); ${ }^{3}$ Patients identified according to CHAARTED criteria (see respective box; Sweeny et al. $N$ Engl $J$ Med 2015;373:737-46); ${ }^{4}$ Patients identified according to LATITUDE criteria (see respective box; Fizazi et al. N Engl J Med 2017;377:352-60); ${ }^{5}$ Patients who are ineligible for either docetaxel or abiraterone for medical reasons or patient preference should be offered alternate agent, if appropriate; ${ }^{6} \mathrm{PSA}$ Progression as defined by PCWG2 criteria. (B) Management of newly diagnosed metastatic castration-resistant prostate cancer. ${ }^{1}$ Clinician should consider performance status, symptoms, comorbidities, location and extent of disease, patient preference, and previous treatment for hormone-sensitive mPC; ${ }^{2} \mathrm{ARAT}=$ abiraterone + prednisone, or enzalutamide; ${ }^{3}$ Use of docetaxel for first-line mCRPC may become more common, given approval of AAP for metastatic castration-sensitive prostate cancer; ${ }^{4} \mathrm{PSA}$ progression as defined by PCWG2 criteria; ${ }^{5}$ Consider palliative care options; ${ }^{6}$ If docetaxelineligible for medical reasons or patient preference, consider referral to tertiary care centre; ${ }^{7}$ If docetaxel or radium-223 ineligible for medical reasons or patient preference, consider use of alternate agent if appropriate; ${ }^{8}$ Radium-223 is indicated for patients with symptomatic bone metastases; ${ }^{9}$ If cabazitaxel or ARAT therapy ineligible for medical reasons or patient preference, consider use of alternate agent if appropriate. AAP: abiraterone acetate and prednisone; ADT: androgen-deprivation therapy; ARAT: androgen receptor axis targeted therapy; GU:

genitourinary; LDH: lactate dehydrogenase; mCRPC: metastatic castration-resistant prostate cancer; mPC: metastatic prostate cancer; PCWG2: prostate cancer working group 2; PSA: prostate-specific antigen. 


\section{Management of metastatic prostate cancer}

\begin{tabular}{|l|l|}
\hline \multicolumn{1}{|c|}{ High-Volume $^{3}$} \\
(CHAARTED)
\end{tabular}

High-Risk ${ }^{4}$

(LATITUDE)

At least two high-risk

factors:

- Visceral metastases

- $\geq 3$ bone lesions

- Gleason score $\geq 8$
Begin treatment for mCRPC

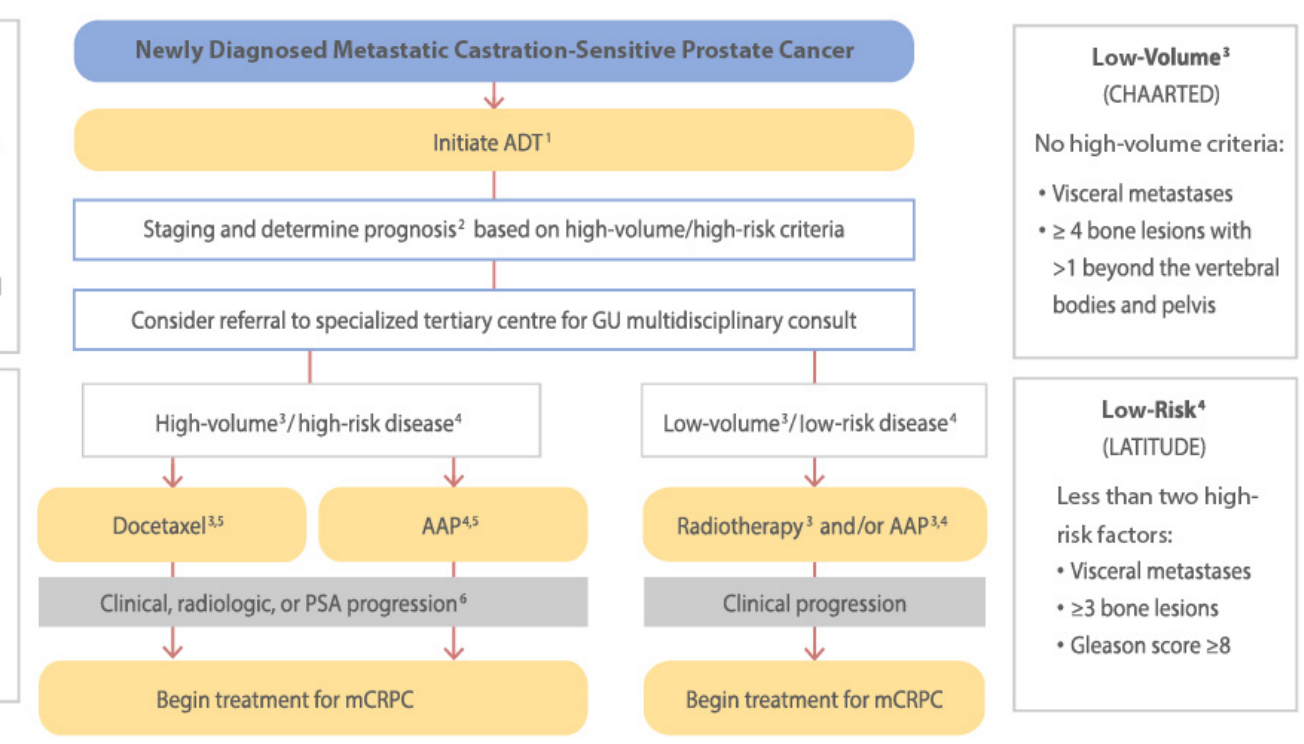

B

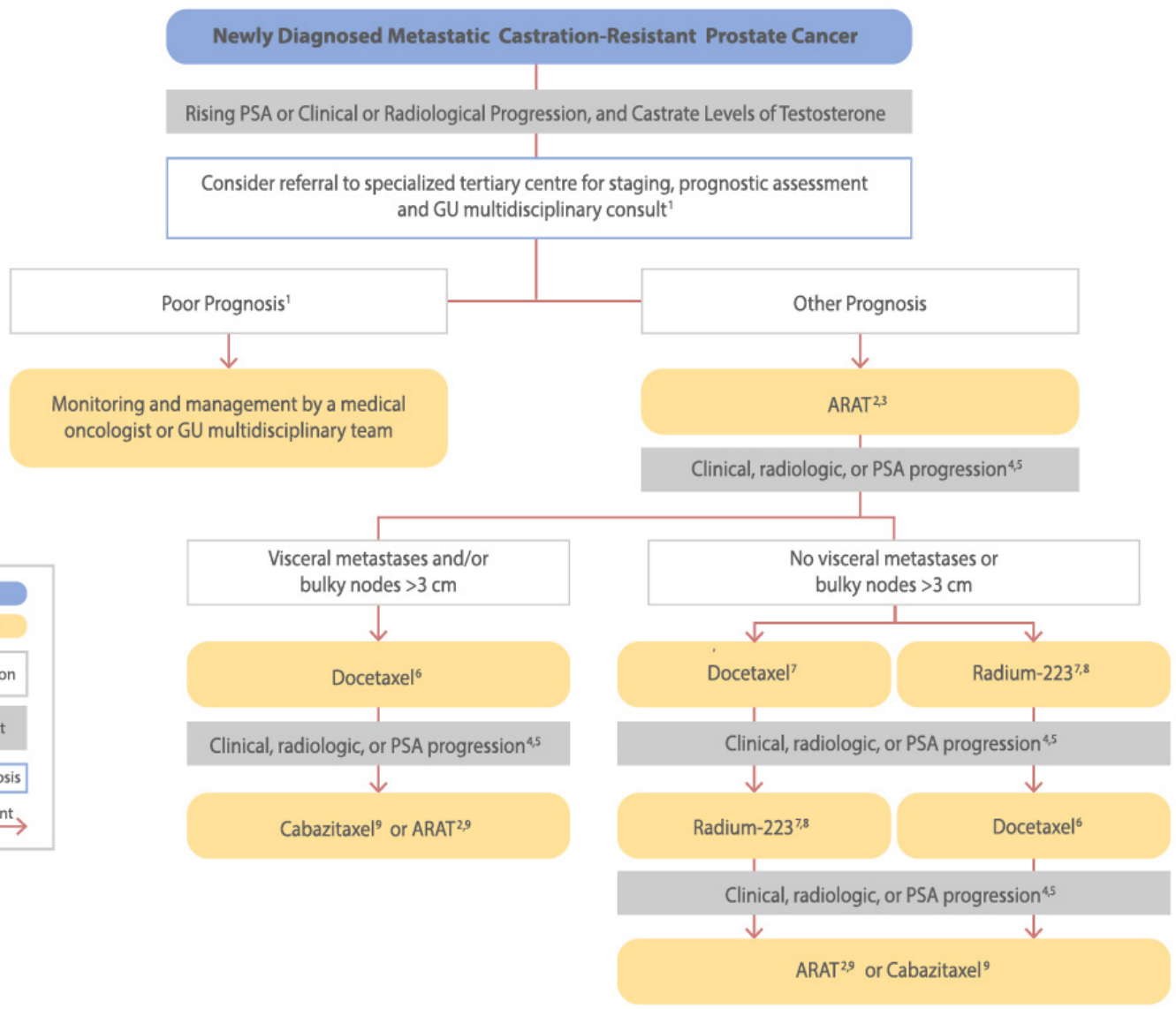




\begin{tabular}{|l|l|l|}
\hline \multicolumn{2}{|l|}{ Table 1. Guidelines, consensus-based guidance considered in development of the } \\
GURC algorithms & Year & Region \\
\hline Guidelines and consensus statements & 2018 & American \\
\hline NCCN prostate cancer guidelines & 2018 & European \\
\hline EAU-ESTRO-ESUR-SIOG guidelines on prostate cancer & 2017 & International \\
\hline Advanced Prostate Cancer Consensus Conference (APCCC) & 2015 & Canadian \\
\hline CUA-CUOG CRPC guidelines & 2015 & European \\
\hline $\begin{array}{l}\text { ESMO clinical practice guidelines on prostate cancer } \\
\text { AUA CRPC guidelines }\end{array}$ & 2015 & American \\
\hline $\begin{array}{l}\text { Phase } 3 \text { addressing treatment of metastatic prostate } \\
\text { cancer }\end{array}$ & & Year \\
\hline $\begin{array}{l}\text { PRINCE (intermittent vs. continuous docetaxel) } \\
\text { STAMPEDE (addition of radiotherapy to ADT vs. ADT) } \\
\text { HORRAD (addition of radiotherapy to ADT vs. ADT }\end{array}$ & \begin{tabular}{l}
2018 \\
2018 \\
\hline
\end{tabular} & 2018 \\
\hline
\end{tabular}

AUA: American Urological Association; CUA-CUOG: Canadian Urological AssociationCanadian Urologic Oncology Group; CRPC: castration-resistant prostate cancer; EAU-ESTROESUR-SIOG: European Association of Urology-European Society for Radiotherapy \& Oncology-European Society of Urogenital Radiology-International Society of Geriatric Oncology; GURC: Genitourinary Research Consortium; NCCN: National Comprehensive Cancer Network. 


\begin{tabular}{|c|c|c|c|}
\hline $\begin{array}{l}\text { Study name } \\
\text { and } \\
\text { Author/Year }\end{array}$ & Setting & $\begin{array}{l}\text { Comparison } \\
\text { stratification }\end{array}$ & Main outcome(s) \\
\hline \multicolumn{4}{|l|}{ Docetaxel } \\
\hline $\begin{array}{l}\text { CHAARTED } \\
\text { Kyriakopoulos, } \\
\text { et al. } 2018^{34}\end{array}$ & $\begin{array}{ll}- & \text { Newly diagnosed } \\
\text { metastatic PCa } \\
-\quad \text { ECOG PS 0-2 } \\
-\quad \text { Prior ADT allowed } \\
\quad \text { if started } \leq 120 \\
\text { days before } \\
\text { randomization }\end{array}$ & $\begin{array}{l}\text { ADT + docetaxel } \\
(\mathrm{n}=397) \text { vs. ADT } \\
(\mathrm{n}=393) \\
\text { Stratified by extent } \\
\text { of metastases: } \\
\text { - } \quad \text { High-volume } \\
\text { (defined as the } \\
\text { presence of } \\
\text { visceral } \\
\text { metastases or } \geq 4 \\
\text { bone lesions } \\
\text { with } \geq 1 \text { beyond } \\
\text { the vertebral } \\
\text { bodies and } \\
\text { pelvis) vs. low- } \\
\text { volume }\end{array}$ & $\begin{array}{l}\text { Median followup: } 53.7 \\
\text { months } \\
\text { Median OS } \\
\text { ITT: } 57.6 \text { vs. } 47.2 \text { months } \\
\text { (HR 0.72; } 95 \% \text { CI } 0.59-0.89 \text {; } \\
\text { p=0.0018) } \\
\text { High-volume disease } \\
\text { (n=513): } 51.2 \text { vs. } 34.4 \text { months } \\
\text { (HR 0.63; } 95 \% \text { CI } 0.50-0.79 ; \\
\text { p<0.001) } \\
\text { Low-volume disease } \\
\text { (n=277): } 63.5 \text { vs. NR months } \\
\text { (HR 1.04; } 95 \% \text { CI } 0.70-1.55 ; \\
\text { p=0.86) }\end{array}$ \\
\hline $\begin{array}{l}\text { STAMPEDE } \\
\text { James, et al. } \\
2016^{32}\end{array}$ & $\begin{array}{l}\text { Newly diagnosed } \\
\text { metastatic or high- } \\
\text { risk locally } \\
\text { advanced PCa or } \\
\text { relapsing with } \\
\text { high-risk features } \\
\text { after prior RP, RT } \\
\text { or both } \\
-\quad \text { Prior ADT allowed } \\
\text { if started } \leq 12 \\
\text { weeks before } \\
\text { randomization } \\
\end{array}$ & $\begin{array}{l}\text { SOC }(\text { ADT })+ \\
\text { docetaxel }(\mathrm{n}=592) \\
\text { vs. SOC (ADT; } \\
\text { n=1184) } \\
\text { - Stratified by } \\
\text { metastasis status, } \\
\text { nodal status and } \\
\text { Gleason score } \\
\text { (among others) }\end{array}$ & $\begin{array}{l}\text { Median followup: } 43 \text { months } \\
\text { Median OS } \\
\text { ITT: } 81 \text { vs. } 71 \text { months (HR } \\
0.78 ; 95 \% \text { CI } 0.66-0.93 ; \\
\text { p=0.006) } \\
\text { M1 subgroup: } 60 \text { vs. } 45 \\
\text { months (HR } 0.76 \text {; } 95 \% \text { CI } \\
0.62-0.92 ; p=0.005 \text { ) }\end{array}$ \\
\hline \multicolumn{4}{|l|}{ AAP } \\
\hline $\begin{array}{l}\text { LATITUDE } \\
\text { Fizazi, et al. } \\
2017^{30}\end{array}$ & $\begin{array}{ll}- & \text { High-risk PCa } \\
- & \text { Chemo, RT-naive } \\
- & \text { No prior surgery } \\
& \text { for metastatic } \\
& \text { disease } \\
- & \leq 3 \text { mo. ADT or } \\
& \text { orchiectomy } \pm \text { AR } \\
& \text { antagonists } \\
\end{array}$ & $\begin{array}{l}\text { ADT }+ \text { AAP }(n= \\
\text { 597) vs. ADT }+ \\
\text { dual placebos } \\
(n=602) \\
\text { Stratified by: } \\
-\quad \text { Presence or } \\
\quad \text { absence of }\end{array}$ & $\begin{array}{l}\text { Median followup: } 30.4 \\
\text { months } \\
\text { Median OS } \\
\text { ITT: NYR vs. } 34.7 \text { months } \\
\text { (HR 0.62; 95\% CI } 0.51-0.76 \text {; } \\
\text { p }<0.001 \text { ) }\end{array}$ \\
\hline
\end{tabular}




\begin{tabular}{|c|c|c|c|}
\hline & & $\begin{array}{ll} & \text { measurable } \\
& \text { visceral disease } \\
-\quad & \text { ECOG PS (0 or } \\
& 1 \text { vs. } 2)\end{array}$ & \\
\hline $\begin{array}{l}\text { STAMPEDE } \\
\text { James, et al. } \\
2017^{31} \\
\text { Hoyle et al. } \\
2018^{36}\end{array}$ & 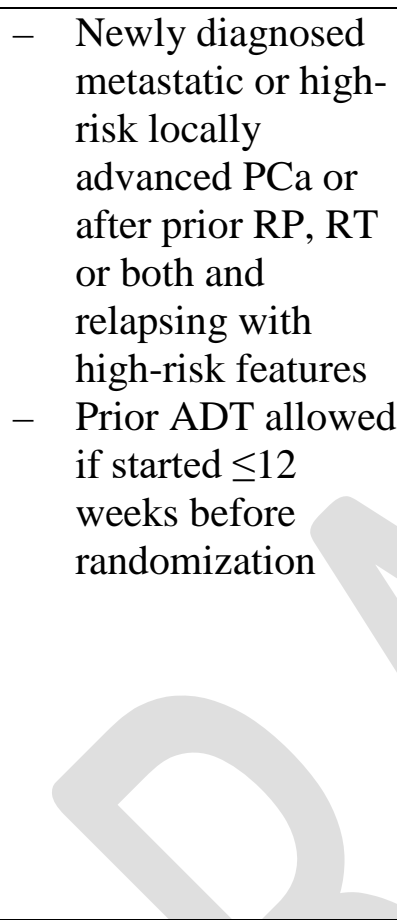 & $\begin{array}{l}\text { SOC (ADT) + AAP } \\
\text { (n=960) vs. SOC } \\
\text { (ADT; n=957) } \\
\text { - Stratified by } \\
\text { metastasis status, } \\
\text { nodal status and } \\
\text { Gleason score } \\
\text { (among others) }\end{array}$ & $\begin{array}{l}\text { Median followup: } 40 \text { months } \\
\text { Median OS } \\
\text { ITT: NYR } \\
\text { 3-year survival } \\
\text { ITT: 83\% vs. 76\% (HR } \\
\text { 0.63; 95\% CI 0.52-0.76; } \\
\text { p<0.001) } \\
\text { M1 subgroup: HR 0.61 } \\
\text { (0.49-0.75) } \\
\text { High-risk M1: 64.7\% vs. } \\
\text { 45\% (HR 0.54; 95\% CI 0.41- } \\
\text { 0.70; p<0.001) } \\
\text { Low-risk M1: 82.4\% vs } \\
\text { 78\% (HR 0.66; 95\% CI 0.44- } \\
\text { 0.98; p=0.041) } \\
\text { High-volume M1: HR 0.60; } \\
\text { 95\% CI 0.46-0.78; p<0.001 } \\
\text { Low-volume M1: HR } 0.64 ; \\
\text { 95\% CI 0.42-0.97; p=0.034 }\end{array}$ \\
\hline \multicolumn{4}{|c|}{ Docetaxel vs. AAP } \\
\hline $\begin{array}{l}\text { STAMPEDE } \\
\text { Sydes, et al. } \\
2018^{35}\end{array}$ & $\begin{array}{l}\text { Newly diagnosed } \\
\text { metastatic or high- } \\
\text { risk locally } \\
\text { advanced PCa or } \\
\text { after prior RP, RT } \\
\text { or both and } \\
\text { relapsing with } \\
\text { high-risk features } \\
-\quad \text { Prior ADT allowed } \\
\text { if started } \leq 12 \\
\text { weeks before } \\
\text { randomization }\end{array}$ & $\begin{array}{l}\text { SOC (ADT) + } \\
\text { docetaxel }(n=189) \\
\text { vs. SOC (ADT) + } \\
\text { AAP (n=377) } \\
\text {-Stratified by } \\
\text { metastasis status, } \\
\text { nodal status and } \\
\text { Gleason score } \\
\text { (among others) }\end{array}$ & $\begin{array}{l}\text { Median followup: } 48 \text { months } \\
\text { Median OS: NYR } \\
\text { 3-year survival } \\
\text { ITT: } 83 \% \text { vs. 78\% (HR 1.16; } \\
\text { 95\% CI } 0.82-1.65 ; \mathrm{p}=0.404 \text { ) } \\
\text { M1 subgroup: HR } 1.13 \text {; 95\% } \\
\text { CI } 0.77-1.66 \text {; } \mathrm{p}=0.528\end{array}$ \\
\hline
\end{tabular}




\begin{tabular}{|c|c|c|c|}
\hline $\begin{array}{l}\text { STAMPEDE } \\
\text { Parker, et al. } \\
2018^{27}\end{array}$ & $\begin{array}{ll}- & \text { Newly diagnosed } \\
\text { metastatic PCa } \\
\text { with no prior } \\
\text { radical treatment } \\
-\quad \text { Intended for long- } \\
\text { term ADT } \\
-\quad \text { Prior ADT allowed } \\
\text { if started } \leq 12 \\
\text { weeks before } \\
\text { randomization }\end{array}$ & $\begin{array}{l}\text { SOC (ADT) + RT } \\
\text { (n=1032) vs. SOC } \\
\text { (ADT; n=1029) } \\
\text { - Stratified by nodal } \\
\text { involvement, } \\
\text { WHO } \\
\text { performance } \\
\text { status, metastatic } \\
\text { burden, planned } \\
\text { ADT, and planned } \\
\text { docetaxel use } \\
\text { (among others) }\end{array}$ & $\begin{array}{l}\text { Median followup: } 37 \text { months } \\
\text { Median OS } \\
\text { ITT: } 48 \text { vs. } 46 \text { months (HR } \\
0.92 ; 95 \% \text { CI } 0.80-1.06 ; \\
\text { p=0.266) } \\
\text { 3-year survival } \\
\text { Low-volume: } 81 \% \text { vs. } 73 \% \\
\text { (HR } 0.68 \text {; } 95 \% \text { CI } 0.52-0.90 \text {; } \\
\text { p=0.007) }\end{array}$ \\
\hline $\begin{array}{l}\text { HORRAD } \\
\text { Boeve et al. } \\
2018^{25}\end{array}$ & $\begin{array}{ll}\text { - } & \text { Newly diagnosed, } \\
\text { primary bone } \\
\text { metastatic PCa } \\
\text { _ } & \text { PSA }>20 \mathrm{ng} / \mathrm{ml}\end{array}$ & $\begin{array}{l}\text { ADT + RT }(n=215) \\
\text { vs. ADT }(n=216)\end{array}$ & $\begin{array}{l}\text { Median followup: } 47 \text { months } \\
\text { Median OS } \\
45 \text { vs. } 43 \text { months (HR } 0.90 ; \\
95 \% \text { CI } 0.70-1.14 ; \mathrm{p}=0.4 \text { ) } \\
\text { Low-volume: HR } 0.68 ; 95 \% \\
\text { CI } 0.42-1.10\end{array}$ \\
\hline
\end{tabular}

${ }^{a}$ At least two of the following high-risk factors: visceral metastasis, $\geq 3$ bone lesions, Gleason score $\geq 8 .{ }^{b}$ Estimated from Kaplan-Meier survival plot for ITT. AAP: abiraterone acetate plus prednisone; ADT: androgen-deprivation therapy; AR: androgen receptor; CI: confidence interval; ECOG PS: Eastern Cooperative Oncology Group performance status; HR: hazard ratio; ITT: intention to treat population; LHRHA: luteinizing hormone releasing hormone antagonist; M1: metastatic; mCSPC: metastatic castration-sensitive prostate cancer; NR: not reported; NYR: not yet reached; OS: overall survival; PCa: prostate cancer; PFS: progression-free survival; PSA: prostate-specific antigen; rPFS, radiographic progression-free survival; RP: radical prostatectomy; RT: radiation therapy; SOC: standard of care. WHO: 


\begin{tabular}{|c|c|c|c|}
\hline $\begin{array}{l}\text { Study name and } \\
\text { author/year }\end{array}$ & Setting & Comparison & Main outcome \\
\hline \multicolumn{4}{|l|}{ Sipuleucel-T } \\
\hline Kantoff, et al. $2010^{48}$ & $\begin{array}{l}\text { Some with previous } \\
\text { docetaxel; ECOG PS } \\
0-1 \text {; asymptomatic or } \\
\text { mildly symptomatic }\end{array}$ & $\begin{array}{l}\text { Sipuleucel-T }(n=341) \\
\text { vs. placebo }(n=171)\end{array}$ & $\begin{array}{l}\text { Followup: } 34.1 \\
\text { months } \\
\text { OS: } 25.8 \text { vs. } 21.7 \\
\text { months (HR 0.78; } \\
\text { 95\% CI 0.61-0.98; } \\
\text { p=0.03) }\end{array}$ \\
\hline Small, et al. $2006^{49}$ & $\begin{array}{l}\text { No corticosteroids; } \\
\text { ECOG PS 0-1; no } \\
\text { bone or cancer pain; } \\
\text { no visceral } \\
\text { metastases }\end{array}$ & $\begin{array}{l}\text { Sipuleucel-T }(n=82) \\
\text { vs. placebo }(n=45)\end{array}$ & $\begin{array}{l}\text { Followup: } 36 \text { months } \\
\text { OS: } 25.9 \text { vs. } 21.4 \\
\text { months (log-rank } \\
\text { HR } 1.70 ; 95 \% \text { CI } \\
\text { 1.13-2.56; p=0.01) }\end{array}$ \\
\hline \multicolumn{4}{|l|}{ Docetaxel } \\
\hline $\begin{array}{l}\text { SWOG 99-16 } \\
\text { Petrylak, et al. } 2004^{52}\end{array}$ & $\begin{array}{l}\text { Chemo-naive; } \\
\text { SWOG PS 0-3; } \\
\text { asymptomatic or } \\
\text { symptomatic }\end{array}$ & $\begin{array}{l}\text { docetaxel/EMP every } \\
3 \text { weeks + EMP } 3 \\
\text { times/day }(n=338) \\
\text { vs. } \\
\text { mitoxantrone every } 3 \\
\text { weeks + prednisone } \\
\text { BID ( } n=336)\end{array}$ & $\begin{array}{l}\text { Follow-up: } 32 \\
\text { months } \\
\text { OS: } 17.52 \text { vs. } 15.6 \\
\text { months (HR 0.80, } \\
\text { 95\% CI 0.67-0.97, } \\
\text { p=0.02) }\end{array}$ \\
\hline $\begin{array}{l}\text { TAX } 327 \\
\text { Tannock, et al. } \\
2004^{53}\end{array}$ & $\begin{array}{l}\text { Chemo-naive; } 13 \% \\
\text { with Karnofsky PS } \\
>70 \% \text {; asymptomatic } \\
\text { or symptomatic }\end{array}$ & $\begin{array}{l}\text { Docetaxel every } 3 \\
\text { weeks }+ \text { prednisone } \\
\text { BID }(n=335) \\
\text { vs. mitoxantrone } \\
\text { every } 3 \text { weeks }+ \\
\text { prednisone BID } \\
(n=337)\end{array}$ & $\begin{array}{l}\text { Followup: } 20.8 \\
\text { months } \\
\text { OS: } 18.9 \text { vs. } 16.5 \\
\text { months for weekly } \\
\text { (HR 0.76; } 95 \% \text { CI } \\
0.62-0.94 ; p=0.009 \text { ) }\end{array}$ \\
\hline $\begin{array}{l}\text { PRINCE } \\
\text { Cash, et al. } 2018^{26}\end{array}$ & $\begin{array}{l}\text { Chemo-naive with } \\
\text { primarily bone } \\
\text { metastatic disease; } \\
\text { Karnofsky PS } \geq 60 \%\end{array}$ & $\begin{array}{l}\text { Intermittent weekly } \\
\text { or } 3 \text {-weekly } \\
\text { docetaxel ( } 35 \mathrm{mg} / \mathrm{m}^{2} \\
\text { or } 75 \mathrm{mg} / \mathrm{m}^{2}, \\
\text { respectively) } \\
\text { vs. } \\
\text { continuous weekly or } \\
\text { 3-weekly docetaxel } \\
\text { (35 mg/m } \mathrm{m}^{2} \text { or } 75 \\
\mathrm{mg} / \mathrm{m}^{2}, \text { respectively) }\end{array}$ & $\begin{array}{l}\text { Followup: } 26.8 \\
\text { months vs. } 33.8 \\
\text { months ( } p=0.396) \\
\text { 1-year OS: } 78 \% \text { vs. } \\
\text { 75\% (non-inferiority } \\
\text { criteria met; two- } \\
\text { sided 95\% CI -12- } \\
\text { 18; } p=0.022 \text { ) }\end{array}$ \\
\hline
\end{tabular}




\begin{tabular}{|c|c|c|c|}
\hline \multicolumn{4}{|l|}{ Abiraterone } \\
\hline $\begin{array}{l}\text { COU-AA-302 } \\
\text { Ryan, et al. } 2015^{51}\end{array}$ & $\begin{array}{l}\text { No previous } \\
\text { docetaxel; ECOG PS } \\
0-1 \text {; PSA or } \\
\text { radiographic } \\
\text { progression; } \\
\text { asymptomatic or } \\
\text { mildly symptomatic; } \\
\text { no visceral } \\
\text { metastases }\end{array}$ & $\begin{array}{l}\text { Abiraterone }+ \\
\text { prednisone }(n=546) \\
\text { vs. placebo }+ \\
\text { prednisone }(n=542)\end{array}$ & $\begin{array}{l}\text { Followup: } 49.2 \\
\text { months } \\
\text { OS: } 34.7 \text { vs. } 30.3 \\
\text { months (HR 0.81; } \\
\text { 95\% CI 0.70-0.93; } \\
\text { p=0.0033) }\end{array}$ \\
\hline \multicolumn{4}{|l|}{ Enzalutamide } \\
\hline $\begin{array}{l}\text { PREVAIL } \\
\text { Beer, et al. } 2014^{50}\end{array}$ & $\begin{array}{l}\text { No previous } \\
\text { docetaxel; ECOG PS } \\
0-1 \text {; PSA or } \\
\text { radiographic } \\
\text { progression; } \\
\text { asymptomatic or } \\
\text { mildly symptomatic; } \\
10 \% \text { had visceral } \\
\text { metastases }\end{array}$ & $\begin{array}{l}\text { Enzalutamide } \\
(n=872 ; \text { rPFS } n=832) \\
\text { vs. placebo }(n=845 ; \\
\text { rPFS } n=801)\end{array}$ & $\begin{array}{l}\text { Followup: } 22 \text { months } \\
\text { OS: } 32.4 \text { vs. } 30.2 \\
\text { months (HR 0.71; } \\
\text { 95\% CI 0.60-0.84; } \\
\text { p<0.001) }\end{array}$ \\
\hline \multicolumn{4}{|l|}{ Radium-233 } \\
\hline $\begin{array}{l}\text { ALSYMPCA } \\
\text { Parker, et al. } 2013^{55} \\
\text { Hoskin, et al. } 2014^{56}\end{array}$ & $\begin{array}{l}\text { Previous or no } \\
\text { previous docetaxel; } \\
\text { ECOG PS 0-2; two } \\
\text { or more symptomatic } \\
\text { bone metastases; no } \\
\text { visceral metastases }\end{array}$ & $\begin{array}{l}\text { Radium-223 (n=614; } \\
\text { docetaxel-naive } \\
n=236) \\
\text { vs. placebo ( } n=307 ; \\
\text { docetaxel-naive } \\
n=113 \text { ) }\end{array}$ & $\begin{array}{l}\text { OS (ITT): } 14.9 \text { vs. } \\
11.3 \text { months (HR } \\
0.70 ; 95 \% \text { CI } 0.58- \\
0.83 ; \mathrm{p}<0.001 \text { ) } \\
\text { OS (docetaxel- } \\
\text { naive): } 16.1 \text { vs. } 11.5 \\
\text { months (HR 0.69; } \\
\text { 95\% CI 0.52-0.92; } \\
\text { p=0.01) }\end{array}$ \\
\hline
\end{tabular}

*Only studies reporting survival outcomes as primary endpoints have been included. BID: twice a day; CI: confidence interval; ECOG: Eastern Cooperative Oncology Group; EMP: estramustine; FU: followup; HR, hazard ratio; mCRPC: metastatic castration-resistant prostate cancer; OS: overall survival; PFS: progression-free survival; PS: performance status; PSA: prostate-specific antigen; rPFS: radiographic progression-free survival. 


\begin{tabular}{|c|c|c|c|}
\hline $\begin{array}{l}\text { Study name and } \\
\text { author/year }\end{array}$ & Setting & Comparison & Main outcome \\
\hline \multicolumn{4}{|l|}{ Abiraterone } \\
\hline $\begin{array}{l}\text { COU-AA-301 } \\
\text { Fizazi, et al. } 2012^{58}\end{array}$ & $\begin{array}{l}\text { Previous docetaxel; } \\
\text { ECOG PS 0-2; PSA } \\
\text { or radiographic } \\
\text { progression }\end{array}$ & $\begin{array}{l}\text { Abiraterone }+ \\
\text { prednisone }(n=797) \\
\text { vs. placebo }+ \\
\text { prednisone }(n=398)\end{array}$ & $\begin{array}{l}\text { Followup: } 20.2 \text { months } \\
\text { OS: } 15.8 \text { vs. } 11.2 \\
\text { months (HR } 0.74 ; 95 \% \\
\text { CI } 0.64-0.86 ; \mathrm{p}<0.0001 \text { ) }\end{array}$ \\
\hline $\begin{array}{l}\text { COU-AA-301 } \\
\text { de Bono, et al. } \\
2011^{66}\end{array}$ & $\begin{array}{l}\text { Previous docetaxel; } \\
\text { ECOG PS 0-2; PSA } \\
\text { or radiographic } \\
\text { progression }\end{array}$ & $\begin{array}{l}\text { Abiraterone }+ \\
\text { prednisone }(n=797) \\
\text { vs. placebo }+ \\
\text { prednisone }(n=398)\end{array}$ & $\begin{array}{l}\text { Followup: } 12.8 \text { months } \\
\text { OS: } 14.8 \text { vs. } 10.9 \\
\text { months (HR } 0.65 ; 95 \% \\
\text { CI } 0.54-0.77 ; \mathrm{p}<0.001 \text { ) }\end{array}$ \\
\hline \multicolumn{4}{|l|}{ Radium-223 } \\
\hline $\begin{array}{l}\text { ALSYMPCA } \\
\text { Hoskin, et al. } 2014^{56}\end{array}$ & $\begin{array}{l}\text { Previous or no } \\
\text { previous docetaxel; } \\
\text { ECOG PS 0-2; two } \\
\text { or more } \\
\text { symptomatic bone } \\
\text { metastases; no } \\
\text { visceral metastases }\end{array}$ & $\begin{array}{l}\text { Radium-223 (prior } \\
\text { docetaxel } n=352 \text { ) } \\
\text { vs. placebo (prior } \\
\text { docetaxel } n=174 \text { ) }\end{array}$ & $\begin{array}{l}\text { OS (prior docetaxel): } \\
14.4 \text { vs. } 11.3 \text { months } \\
\text { (HR } 0.70 ; 95 \% \text { CI } 0.56- \\
0.88 ; p=0.002)\end{array}$ \\
\hline \multicolumn{4}{|l|}{ Cabazitaxel } \\
\hline $\begin{array}{l}\text { TROPIC } \\
\text { de Bono, et al. } \\
2010^{60} \\
\text { Bahl, et al. } 2013^{67}\end{array}$ & $\begin{array}{l}\text { Previous docetaxel; } \\
\text { ECOG PS 0-2 }\end{array}$ & $\begin{array}{l}\text { Cabazitaxel }+ \\
\text { prednisone }(n=378) \\
\text { vs. mitoxantrone }+ \\
\text { prednisone }(n=377)\end{array}$ & $\begin{array}{l}\text { Followup: } 12.8 \text { months } \\
\text { OS: } 15.1 \text { vs. } 12.7 \\
\text { months (HR } 0.70 ; 95 \% \\
\text { CI 0.59-0.83; } \mathrm{p}<0.0001 \text { ) } \\
\text { Followup: } 25.5 \text { months } \\
\text { OS: } 318 / 378 \text { vs. } \\
\text { 346/377 events (odds } \\
\text { ratio 2.11; } 95 \% \text { CI } 1.33- \\
\text { 3.33) } \\
\text { OS } \geq 2 \text { years } 27 \% \text { vs. } \\
\text { 16\% }\end{array}$ \\
\hline \multicolumn{4}{|l|}{ Enzalutamide } \\
\hline AFFIRM & Previous docetaxel; & Enzalutamide & Followup: 14.4 months \\
\hline
\end{tabular}




\begin{tabular}{|l|l|l|l|}
\hline Scher, et al. 2012 & ECOG PS 0-2 & $\begin{array}{l}(\mathrm{n}=800) \\
\text { vs. placebo }(\mathrm{n}=399)\end{array}$ & $\begin{array}{l}\text { OS: } 18.4 \text { vs. 13.6 } \\
\text { months (HR 0.63; 95\% } \\
\text { CI 0.53-0.75; } \mathrm{p}<0.001)\end{array}$ \\
\hline
\end{tabular}

*Only studies reporting survival outcomes as primary endpoints have been included. CI: confidence interval; ECOG: Eastern Cooperative Oncology Group; HR: hazard ratio; OS: overall survival; PFS: progression-free survival; PSA: prostate-specific antigen; rPFS: radiologic progression-free survival. 